\title{
Analisis Hidrograf DAS Poso dengan Metode Hidrograf Satuan Sintetis Snyder dan Hidrograf Satuan Sintetis Soil Conversation Service [SCS]
}

\author{
A. Kahffi ${ }^{a *}$ dan S. Lipu \\ a Jurusan Teknik Sipil, Fakultas Teknik Universitas Tadulako, Jl. Soekarno-Hatta Km 9, Palu 94118, Indonesia \\ ${ }^{*}$ Corresponding author's e-mail: mr.akaf04@gmail.com
}

Received: 26 July 2021; revised: 12 August 2021; accepted: 18 August 2021

\begin{abstract}
Abstrak: The Poso River is a river located in Poso Regency, Central Sulawesi Province, which has a length of $74.58 \mathrm{~km}$, and watershed area of $1092.810 \mathrm{~km}^{2}$. Energy in the Poso River is used for hydroelectric power plant (PLTA). With the construction of the Poso hydropower plant, maximum flood discharge data is needed for the prevention of Poso hydro power plant safety. In calculating the flood discharge, the method used is a synthetic unit hydrograph. Synthetic unit hydrograph is a graph of the relationship between flow rate (Q) and time (t). In this study, the method used to calculate the designed flood discharge is the Snyder synthetic unit hydrograph method and the Soil Conversation Service (SCS) synthetic unit hydrograph. The aims of this study are to determine the largest flood discharge value and to determine the hydrograph shapes of the two methods. The parameters that will be obtained from both methods are peak time (Tp), base time $(\mathrm{Tb})$ and peak discharge (Qp). From the analysis it can be found that in the Snyder SUH method, the peak time (Tp) is 12.616 hours, the base time $(\mathrm{Tb})$ is 67.276 hours with a peak discharge (Qp) of $21.672 \mathrm{~m}^{3} / \mathrm{sec}$. Whereas in the SCS SUH method, the peak time (Tp) is 10.954 hours, the base time (Tb) is 57.268 hours with a peak discharge (Qp) of $20.751 \mathrm{~m}^{3} / \mathrm{sec}$. The result demonstrates the result that the largest flood discharge has occurred in the Snyder SUH method.
\end{abstract}

Keywords: Poso watershed, flood, Snyder method, Soil Conversation Service (SCS) method.

Abstrak: Sungai Poso merupakan sungai yang terletak di Kabupaten Poso Provinsi Sulawesi Tengah yang memiliki panjang sungai $74.580 \mathrm{~km}$, dan luas DAS $1092.810 \mathrm{~km}^{2}$. Energi pada aliran sungai Poso dijadikan sebagai pembangkit listrik tenaga air (PLTA). Dengan adanya pembangunan PLTA Poso maka dibutuhkan data debit banjir maksimum untuk langka langka preventif keamanan PLTA Poso. Salah satu metode untuk menghitung debit banjir rencana metode yang digunakan ialah hidrograf satuan sintetik. Hidrograf satuan sintetik adalah grafik hubungan antara debit $(\mathrm{Q})$ terhadap waktu $(\mathrm{t})$. Dalam penelitian ini metode yang digunakan untuk menghitung debit banjir rencana ialah metode hidrograf satuan sintetik Snyder dan hidrograf satuan sintetik Soil Conversation Service (SCS), dengan tujuan dari penelitian ini ialah untuk mengetahui nilai debit banjir terbesar dan untuk mengetahui bentuk hidrograf dari kedua metode tersebut. Adapun parameter yang akan didapatkan dari kedua metode tersebut ialah waktu puncak (Tp), waktu dasar (Tb) dan debit puncak (Qp). Dari hasil analisis, pada metode HSS Snyder waktu puncak (Tp) didapatkan sebesar 12.616 Jam, waktu dasar (Tb) sebesar 67.276 Jam dengan debit puncak (Qp) sebesar $21.672 \mathrm{~m}^{3} /$ det. Sedangkan pada metode Soil Conversation Service (SCS) waktu puncak (Tp) didapatkan sebesar 10.954 Jam, waktu dasar (Tb) sebesar 57.268 Jam dengan debit puncak (Qp) sebesar $20.751 \mathrm{~m}^{3} / \mathrm{det}$. Dari hasil tersebut dapat diketahui bahwa debit banjir terbesar terjadi pada metode HSS Snyder.

Kata kunci: DAS Poso, Metode Snyder, Metode Soil Conversation Service (SCS)

\section{Pendahuluan}

Dalam perencanaan sumber daya air dibutuhkan data debit banjir rencana yang realistis. Data curah hujan dan data banjir rencana dapat digunakan untuk menghitung debit banjir. Jika data debit banjir yang tersedia yang tersedia cukup panjang ( $>20$ Tahun), maka metode analisis probabilitas dapat digunakan untuk menghitung debit banjir, sedangkan apabila data yang tersedia hanya berupa data hujan dan karakteristik daerah aliran sungai (DAS) metode yang disarankan ialah Hidrograf Satuan Sintetis [1].

Metode hidrograf satuan sintetik adalah metode yang umum digunakan dan berperan penting dalam berbagai perencanaan di bidang sumber daya air, terutama dalam menganalisis debit banjir DAS yang tidak terukur. Metode ini sangat sederhana, karena hanya membutuhkan data karakteristik DAS seperti Luas DAS dan Panjang sungai. Metode hidrograf satuan sintetik (HSS) banyak digunakan kerena mampu memperkirakan debit berdasarkan sekian waktu pada suatu kejadian hujan, sehingga diperoleh hubungan antara waktu dan debit dalam bentuk hidrograf. Beberapa metode hidrograf satuan sintetik yang populer dan umum digunakan di indonesia untuk menghitung debit puncak dan bentuk hidrograf banjir, seperti HSS ITB-1, HSS ITB-2, HSS Nakayasu, HSS Synder-Alexejev, HSS Limantara HSS Soil Conservation Service (SCS), dan GAMA-1.

Sungai Poso merupakan sungai yang berada di Kabupaten poso yang mempunyai panjang sebesar 74.580 $\mathrm{km}$ dan Luas $1092.810 \mathrm{~km}^{2}$. Aliran sungai tersebut mempunyai debit air yang besar dimana energi air tersebut digunakan sebagai pembangkit listrik tenaga air (PLTA), PLTA Poso dibagi menjadi beberapa bagian yaitu, PLTA Poso 1, PLTA Poso 2, dan PLTA Poso 3. Dengan adanya pembangunan PLTA Poso maka dibutuhkan data debit banjir maksimum untuk langka langka preventif keamanan PLTA Poso. 
Dari latar belakang tersebut penulis terdorong untuk melakukan penelitian di DAS Poso melalui studi kasus“Analisis Hidrograf Satuan Sintetis (HSS) DAS Poso dengan metode HSS Synder dan HSS Soil Conversation Service (SCS)". Dengan mendapatkan hasil debit banjir maksimum dan mengetahui bentuk hidrograf dari kedua metode tersebut.

\section{Metode Penelitian}

\subsection{Lokasi Penelitian}

Daerah aliran sungai (DAS) Poso secara administratif terletak di Kabupaten Poso Provinsi Sulawesi Tengah dengan Panjang Sungai $74.580 \mathrm{~km}$ dan Luas $1092.810 \mathrm{~km}^{2}$ (Gambar 1). Daerah aliran sungai Poso memiliki kondisi topografi perbukitan dan pengunungan dengan elevasi 400-1200 m dengan kemiringan lereng 5\% - 40\% [2]. Daerah aliran sungai Poso merupakan daerah kawasan perkebunan coklat, kelapa, kehutanan dan kawasan pertanian. Peraiaran DAS Poso termasuk daerah dengan potensial bagi sumber daya Ikat Sidat. Daearah aliran sungai Poso membentang dari wilayah Tentena/Danau Poso (hulu) hingga wilayah Kayamanya (hilir) yang merupakan daerah yang berbatasan langsung dengan Teluk Tomini. Secara Geografis Daerah aliran sungai Poso terletak pada kordinat $01^{\circ} 42^{\prime} 01.5^{\prime \prime} \mathrm{LS}$ dan $120^{\circ} 39^{\prime} 11.6^{\prime \prime}$ BT dengan jarak $\pm 208 \mathrm{~km}$ dari Kota Palu dengan Suhu iklmi berkisar $20-23^{\circ} \mathrm{C}$

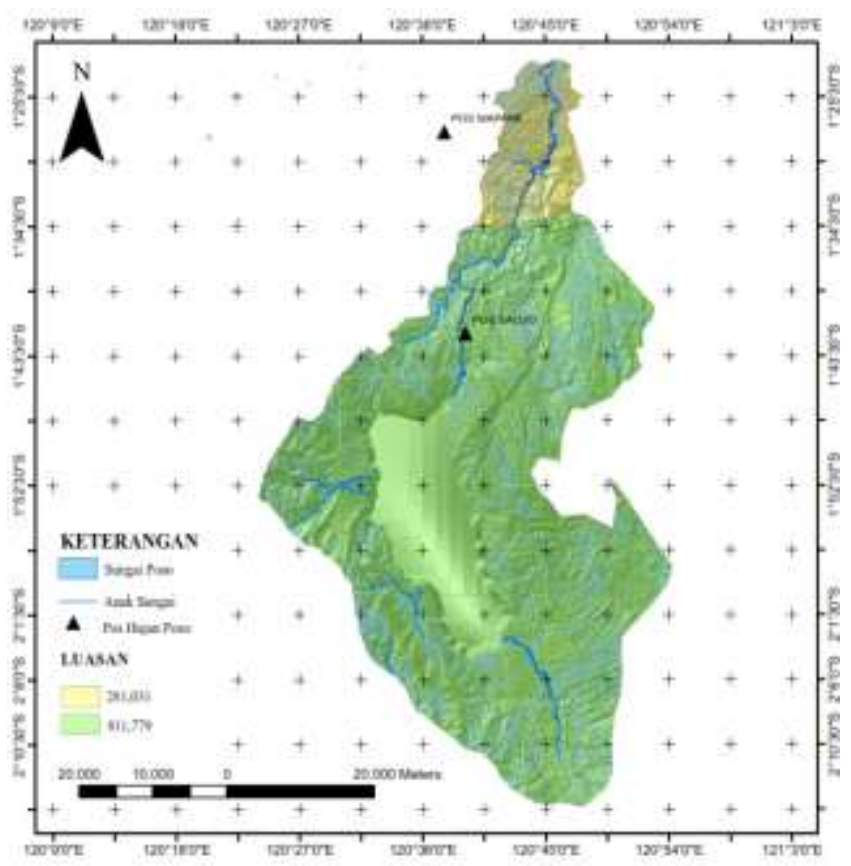

Gambar 1. Peta DAS Poso

\subsection{Pengumpulan Data}

Data yang digunakan dalam penelitian ini ialah data sekunder yang merupakan data hasil pengukuran dan pencatatan yang diperoleh dari Balai Wilayah Sungai Sulawesi III. Adapun data yang diperlukan ialah:

1) Data Curah Hujan Maksimum Pertahun

Data curah hujan dalam penelitian ini dikumpulkan berdasarkan data curah hujan maksimum pertahun yang diperoleh dari stasiun hujan yang berada disekitar daerah penelitian. Untuk menghitung curah hujan rancangan pada DAS Poso digunakan data 10 tahun yang diperoleh dari Balai Wilayah Sulawesi III.

2) Peta Digital Sub DAS Poso

Peta digital sub DAS Poso digunakan untuk mendapatkan informasi seperti luas DAS, lokasi stasiun hujan, panjang sungai dan lebar sungai. Data tersebut diperoleh dari Balai Wilayah Sungai Sulawesi III dan Aplikasi ArcGis.

\subsection{Analisis Data}

Pada tahap analisis data curah hujan yang digunakan bersumber dari Balai Wilayah Sulawesi III, dan untuk menghitung hujan rata rata DAS menggunakan metode Polygon Thissen. Tahapan penenelitian disajikan pada Gambar 2.

1) Menghitung Hidrograf Satuan Sintetis (HSS)

Mengumpulkan terlebih dahulu parameter parameter yang akan digunakan untuk menghitung dengan menggunakan metode HSS Synder-Alexejev dan HSS Soil Conservation Service (SCS).

2) Menggambarkan Grafik Hidrograf Aliran Menggambarkan hidrograf hasil perhitungan HSS yang diperoleh dari metode HSS Synder-Alexejev dan HSS Soil Conservation Service (SCS).

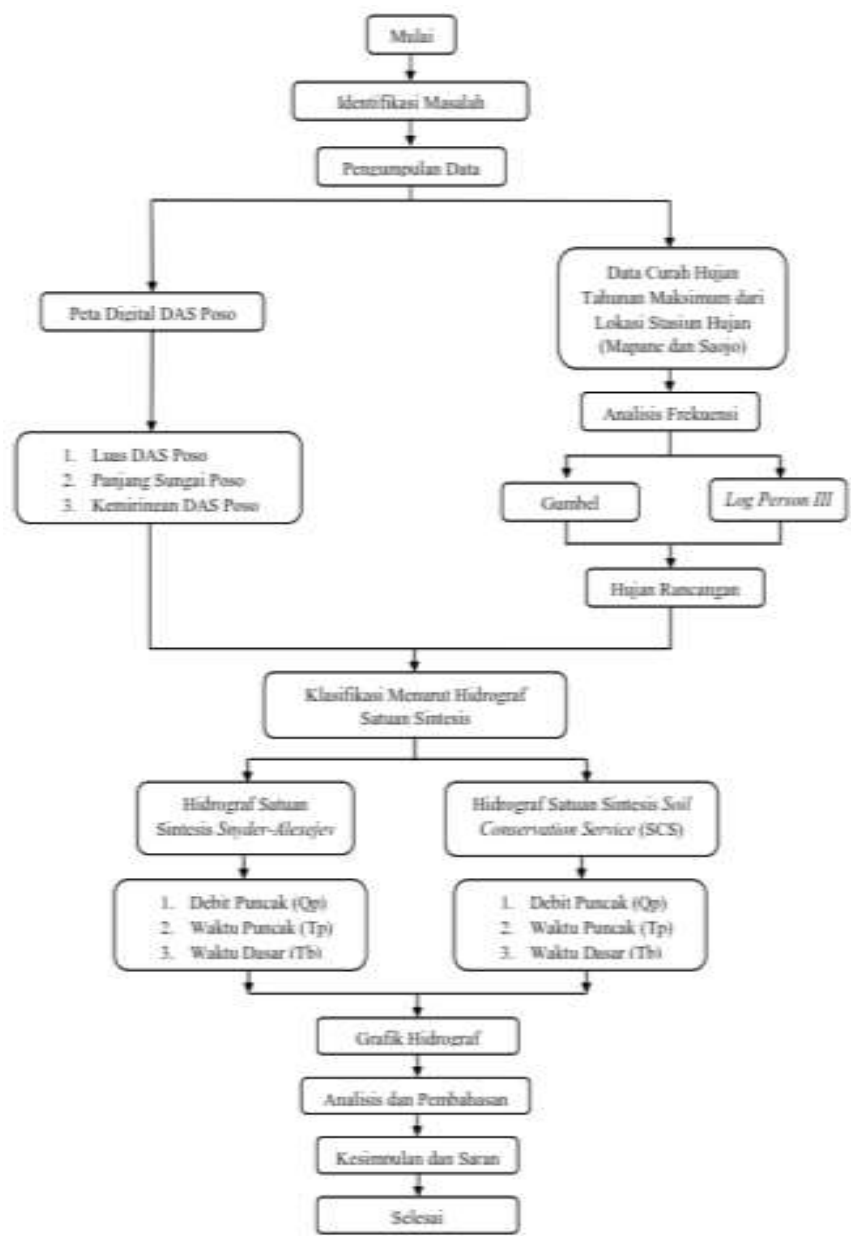

Gambar 2. Bagan Alur Penelitian 


\subsection{Banjir}

Banjir adalah suatu aliran berlebih atau penggenangan yang datang dari sungai atau badan air lainnya dan menyebabkan/mengancam kerusakan. Perbedaan antara debit normal dan aliran banjir ditentukan oleh tinggi aliran air dimana banjir ditunjukkan dengan aliran air yang melampaui kapasitas tampung tebing/tanggul sungai sehingga menggenangi daerah sekitarnya [3].

\subsection{Daerah Aliran Sungai (DAS)}

Daerah aliran sungai (DAS) adalah daerah yang di batasi punggung-punggung gunung dimana air hujan yang jatuh pada daerah tersebut akan ditampung oleh punggung gunung tersebut dan akan dialirkan melalui sungai-sungai kecil ke sungai utama [4].

Daerah tangkapan air (DTA) adalah kawasan di hulu danau yang memasok air ke danau. Wilayah sungai adalah kesatuan wilayah tata pengairan sebagai hasil pengembangan satu atau lebih daerah pengaliran sungai. [5].

\subsection{Analisis Curah Hujan}

Hujan merupakan faktor yang sangat penting didalam analisis maupun desain hidrologi, dan besarnya hujan atau yang disebut sebagai curah hujan kita dapat menghitung dari tebal lapisan air hujan yang jatuh diatas permukaan tanah yang rata dan dinyatakan dalam satuan milimeter $(\mathrm{mm})$. Oleh karena itu dalam suatu rancangan keairan perlu diperhatikan beberapa faktor hujan antara lain: ketebalan hujan atau tinggi curah hujan, distribusi hujan, frekuensi hujan, itensitas hujan, volume hujan dan jumlah hari hujan, sehingga dalam suatu perancangan keairan diperlukan curah hujan rata - rata sering disebut sebagai curah hujan daerah [6].

\subsection{Analisis Curah Hujan Rata Rata DAS}

Dalam analisis hidrologi, umumnya digunakan data hujan yang dianggap dapat mewakili jumlah seluruh hujan yang terjadi dalam DAS. Besaran hujan tersebut diperoleh dengan merata - ratakan hujan titik (point rainfall). Metode yang digunakan dalam analisi hujan rata - rata DAS (catchment rainfall) sebagai berikut [7].

1) Metode Rerata Aritmatik (Aljabar)

$$
\bar{P}=\frac{P 1+P 2+\cdots+P n}{n}
$$

2) Metode Polygon Thiessen

$$
\bar{P}=\frac{A 1 P 1+A 2 P 2+\cdots+A n P n}{A 1+A 2+\cdots+A n}
$$

3) Metode Isohyet

$$
\bar{P}=\frac{A 1 \frac{I 1+I 2}{2}+\cdots+A n \frac{I n+I n}{2}}{A 1+\cdots+A n}
$$

\subsection{Pengukuran Agihan Frequensi}

Suatu kenyataan bahwa tidak semua nilai dari suatu variabel hidrologi terletak atau sama dengan nilai rataratanya, tetapi kemungkinan ada nilai yang lebih besar atau lebih kecil dari nilai rata-ratanya [6]. Besarnya dispersi dapat dilakukan pengukuran dispersi, yakni melalui perhitungan parametrik statistik untuk $\left(\mathrm{x}_{\mathrm{i}}-\mathrm{x}\right)$, $\left(\mathrm{x}_{\mathrm{i}}-\mathrm{x}\right)^{2},\left(\mathrm{x}_{\mathrm{i}}-\mathrm{x}\right)^{3},\left(\mathrm{x}_{\mathrm{i}}-\mathrm{x}\right)^{4}$ terlebih dahulu [7].

1) Deviasi Standart $(\mathrm{S})$

$$
S=\sqrt{\frac{\sum_{i=1}^{n}(x-\bar{x})^{2}}{(n-1)}}
$$

2) Koefisien Skewness (Cs)

$$
C S=\sqrt{\frac{\sum_{i=1}^{n}(x-\bar{x})^{3}}{(n-1)(n-2) S^{3}}}
$$

3) Koefisien Kurtosis (Ck)

$$
C k=\sqrt{\frac{\frac{1}{n} \sum_{i=1}^{n}(x-\bar{x})^{4}}{S^{4}}}
$$

4) Koefisien Variasi (Cv)

$$
C v=\frac{s}{X}
$$

\subsection{Analisis Jenis Sebaran}

Dalam analisis jenis seberan yang digunakan ada 3 metode, yaitu Metode Gumbel, Metode Log Person III, dan Metode Log Normal [7].

a) Metode Gumbel

$$
X T=X+K . S x
$$

b) Metode Log Person III

$$
\log X T=\log X+K \operatorname{Ktr} . S \log x
$$

c) Metode Log Normal

$$
\log X T=\log X+k \cdot S x \log X
$$

\subsection{Pengeplotan Probalitas dan Uji Kecocokan Data}

Untuk mengetahui apakah jenis distribusi yang digunakan memenuhi syarat untuk dijadikan dasar pemilihan debit banjir rancangan dengan periode ulang tertentu maka dilakukan Pengeplotan probabilitas dan uji kecocokan. Metode yang digunakan ialah [8]:

a) Chi kuadrat (Chi Square Test)

Uji chi kuadrat digunakan untuk menguji apakah distribusi pengamatan dapat disamai dengan baik oleh distribusi teoritis. Perhitungannya dengan menggunakan persamaan berikut:

$$
X^{2}=\sum_{i=1}^{n} \frac{(O f . E f)^{2}}{E f}
$$

b) Uji Smirnov Kolmogorov

Uji ini dilakukan dengan membandingkan kemungkinan (probability) untuk setiap variasi dan distribusi empiris dan teoritis, sehingga diperoleh perbedaan $(\Delta)$. Ploting data sama dengan langka langka plotting pada uji chi square, dengan persamaan sminov kolmogorov.

$(P \max |P e-P t|)<\Delta C r, \alpha$

\subsection{Perhitungan Intensitas Hujan}

Perhitungan debit banjir rencana perlu didapatkan harga suatu intensitas curah hujan. Intensitas curah hujan adalah ketinggian curah hujan yang terjadi pada suatu 
kurun waktu dimana air tersebut berkonsentrasi. Analisis intensitas curah hujan tersebut dapat diproses dari data curah hujan yang telah terjadi pada masa lampau.

Durasi adalah lamanya suatu kejadian hujan. Intensitas hujan yang tinggi pada umumnya berlangsung dengan durasi pendek dan meliputi daerah yang tidak luas. Hujan yang meliputi daerah yang luas jarang sekali memiliki intensitas yang tinggi, tetapi dapat berlangsung dengan durasi yang cukup panjang. Kombinasi dari intensitas curah hujan yang tinggi dengan durasi yang panjang jarang terjadi, tetapi apabila terjadi berarti sejumlah besar volume air bagaikan ditumpahkan dari [9].

Adapun rumus sederhana dari intensitas hujan menurut mononobe adalah sebagai berikut [7].

$$
I=\frac{R 24}{24} x \frac{24}{t}
$$

\subsection{Perhitungan Waktu Konsentrasi}

Waktu konsentrasi (Tc) suatu DAS adalah waktu yang diperlukan oleh air hujan yang jatuh untuk mengalir dari titik terjauh sampai ketempat keluaran DAS (titik control) setelah tanah menjadi jenuh dan depresi-depresi kecil terpenuhi. Dalam hal ini diasumsikan bahwa jika durasi hujan sama dengan waktu konsentrasi, maka setiap bagian DAS secara serentak telah menyumbangkan aliran terhadap titik kontrol [9].

Salah satu metode yang dapat digunakan untuk menghitung waktu konsentrasi yng dikembangkan oleh Kirpich (1940), persamaannya:

$\mathrm{Tc}=0.066 \times \mathrm{L}^{0.77} \times \mathrm{S}^{-0.385}$

\subsection{Hidrograf Satuan Sintetis Snyder Alexejev}

Untuk mendapatkan suatu hidrograf satuan dengan data yang baik maka dibutuhkan, yaitu data AWLR, data pengukuran debit, data hujan harian, dan data hujan perjam, yang menjadi permasalahan bahwa karena berbagai sebab data ini sangat sulit diperoleh atau tidak tersedia. Untuk mengatasi hal ini maka dikembangkan suatu cara untuk mendapatkan hidrograf satuan tanpa mempergunakan data tersebut di atas [1]. Salah satu cara tersebut dikembangkan oleh F.F. Synder dari Amerika Serikat pada tahun 1938 yang memanfaatkan parameter DAS untuk memperoleh hidrograf satuan sintetik. Sejumlah DAS yang diteliti oleh Synder berada di dataran tinggi Appalachian dengan luas DAS berkisar antara 30 sampai $30.000 \mathrm{~km}^{2}$ [11-12].

Dalam model HSS Synder berisi 2 parameter non fisik yaitu $\mathrm{Ct}$ dan $\mathrm{Cp}$ yang merupakan koefisien-koefisien yang tergantung pada unit dan karakteristiknya DAS [13]. Besaran nilai $\mathrm{Ct}$ dan $\mathrm{Cp}$ tersebut diperoleh Synder dari sejumlah DAS di dataran tinggi Appalachian Amerika Serikat. Koefisien-koefisien $\mathrm{Ct}$ dan $\mathrm{Cp}$ harus ditentukan secara empirik, karena besarnya berubah-berganti antara satu wilayah dengan daerah lain. Besaran nilai $\mathrm{Ct}$ antara 0.75 sampai 3.00, sedangkan Cp berada antara 0,90 sampai 1,40 [14]. Besaran nilai $\mathrm{Ct}$ dan $\mathrm{Cp}$ tersebut diperoleh Synder untuk sejumlah DAS di dataran tinggi Appalachian Amerika Serikat, dimana bila nilai $\mathrm{Cp}$ mendekati nilai terbesar maka nilai $\mathrm{Ct}$ akan mendekati nilai terkecil, demikian sebaliknya.
Menurut hasil penelitian Hoffmeister dan Weisman pada tahun 1977 [1], bahwa pemakaian parameter Lc oleh Synder disebabkan karena bagian hulu suatu DAS dianggap tidak berpengaruh terhadap debit puncak suatu hidrograf. Mengenai unsur debit puncak, penelitian yang telah dilakukan Morgan dan Johnson pada tahun 1962 [1], menyatakan bahwa persamaan Synder memberikan debit puncak paling kecil dibandingkan dengan cara lain seperti SCS, Common, Mitchell, Nakayasu dan GAMA I.

Unsur unsur hidrograf satuan meliputi: debit Puncak (Qp, $\mathrm{m}^{3}$ /detik), waktu Dasar (Tb, jam) dan durasi hujan (Tp, jam) dan tr (jam). Karakteristik DAS terdiri dari: luas DAS $\left(\mathrm{A}, \mathrm{km}^{2}\right)$, panjang Aliran Utama $(\mathrm{L}, \mathrm{km})$ dan jarak antara titik berat DAS dengan outlet yang diukur di sepanjang aliran utama. (Lc, km).

Adapun tahap perhitungan dengan menggunakan metode hidrograf satuan Sintetik Synder-Alexejev adalah sebagai berikut [15]:

a. Menghitung waktu mulai titik berat hujan sampai debit puncak (tp).

$$
\mathrm{tp}=\mathrm{Ct}(\mathrm{L} \times \mathrm{Lc})^{0.3}
$$

b. Menghitung waktu lama curah hujan efektif (te).

$$
\text { te }=\frac{t p}{5,5}
$$

c. Menghitung waktu dasar (tb).

$$
\mathrm{tb}=5\left(\mathrm{tp}+\frac{t r}{2}\right)
$$

d. Menghitung waktu mencapai puncak banjir (Tp). Karena te $<$ tr, maka untuk mencari nilai tp digunakan persamaan berikut:

$$
\mathrm{tp}=\mathrm{tp}+0,25(\mathrm{tr}-\mathrm{te})
$$

e. Menghitung debit puncak banjir (Qp).

$$
\mathrm{Qp}=0.278 * \frac{C p \cdot A}{T p}
$$

\subsection{Hidrograf Satuan Sintetis Soil Conversation Service (SCS)}

HSS Soil Conservation Service (SCS) merupakan salah satu hidrograf satuan tak berdimensi, artinya bahwa penentuan hidrograf satuan sintetik ditetapkan berdasarkan rasio waktu dan rasio debit yang telah ditetapkan sebelumnya dan berlaku umum untuk setiap DAS yang dievaluasi. Model Hindrograf Satuan Sintetik ini menggunakan 4 buah parameter DAS yaitu luas DAS, panjang sungai utama, kemiringan sungai utama dan Curve Number $(\mathrm{CN})$. Parameter yang terakhir ini penentuannya sangat sulit karena bergantung pada banyak variable terutama jenis tutupan lahan dan karakteristik tanah.selain itu ketersediaan data untuk pemenuhan parameter ini sangat terbatas terutama di Indonesia dengan tingkat penyebaran data yang tidak merata. Namun demikian, parameter ini perannya sangat penting karena sangat berperan pada proses transformasi hujan menjadi limpasan di dalam DAS [16]. Soil Conservation Service (SCS) menggambarkan pengaruh tataguna lahan terhadap 
REKOnSTRUKSI TADULAKO: Civil Engineering Journal on Research and Development, Vol. 2(2), September 2021

limpasan dengan nilai Curve Number (CN). Namun sebenarnya nilai Curve Number (CN) tidak hanya berdasarkan tataguna lahan, tetapi dilihat dari kondisi tanah, vegetasi dan kelengasan tanah pada tutupan lahan tersebut, sehingga dengan karakter tersebut dapat ditentukan nilai Curve Number (CN) untuk Metode Soil Conservation Service (SCS).

Adapun tahap perhitungan dengan menggunakan metode hidrograf satuan Sintetik Soil Conversation Service adalah sebagai berikut [10]:

a) Menghitung Nilai Time Lag (Tl)

$$
T l=L^{0,8} \frac{2540-22,86 C N}{14104 C N^{0,7} S^{0,5}}
$$

b) Menghitung waktu mencapai puncak banjir (Tp)

$$
T p=\frac{t r}{2}+T l
$$

c) Menghitung Waktu Dasar (Tb)

$$
T b=5\left(\operatorname{tp}+\frac{t r}{2}\right)
$$

d) Menghitung Debit Puncak Banjir (Qp)

$$
Q p=\frac{0,208 \cdot A}{T p}
$$

\subsection{Identifikasi Parameter DAS yang mempengaruhi Hidrograf}

\begin{tabular}{|c|c|c|}
\hline No & $\begin{array}{c}\text { Jenis } \\
\text { Hidrograf. }\end{array}$ & $\begin{array}{l}\text { Parameter Hidrograf yang } \\
\text { berpengaruh. }\end{array}$ \\
\hline 1 & $\begin{array}{l}\text { Snyder } \\
\text { Alexejev }\end{array}$ & $\begin{array}{ll}\text { - } & \text { Luas DAS (A) } \\
\text { - } & \text { Panjang sungai (L) } \\
\text { - } & \text { Kemiringan sungai (S). } \\
\text { - } & \text { Jarak antara titik berat DAS } \\
& \text { dengan outlet yang diukur di } \\
& \text { sepanjang aliran utama (Lc) } \\
\text { - } & \text { Lama curah hujan efektif (tr) } \\
\text { - } & \text { Koefisien kelandaian DAS } \\
& (\mathrm{Ct}) \\
\text { - } & \text { Koefisien Kapasitas } \\
& \text { Tampungan (Cp). }\end{array}$ \\
\hline 2 & $\begin{array}{l}\text { Soil } \\
\text { Conversation } \\
\text { Service } \\
\text { (SCS) }\end{array}$ & $\begin{array}{ll}\text { - } & \text { Luas DAS (A) } \\
\text { - } & \text { Panjang sungai (L) } \\
\text { - } & \text { Kemiringan sungai (S) } \\
\text { - } & \text { Lama curah hujan efektif (tr) } \\
\text { - } & \text { Curva Number }(\mathrm{CN}) .\end{array}$ \\
\hline
\end{tabular}

Parameter DAS yang berpengaruh terhadap hidrograf dapat dilihat pada Tabel 1 .

Tabel 1. Parameter yang mempengaruhi Hidrograf

\section{Hasil dan Pembahasan}

\subsection{Data Curah Hujan}

Data curah hujan yang digunakan untuk menghitung curah hujan rancangan pada DAS Poso adalah data curah hujan hasil pengukuran pada stasiun curah hujan Mapane dan Saojo. Untuk menghitung curah hujan rancangan pada DAS Poso digunakan data 10 tahun (Tabel 2) yang diperoleh dari Balai Wilayah Sulawesi III. Data minimal yang digunakan dalam menghitung curah hujan rancangan

\begin{tabular}{|c|c|c|c|c|c|}
\hline \multirow{3}{*}{$\begin{array}{c}\text { Tahun / } \\
\text { Bobot }\end{array}$} & \multicolumn{2}{|c|}{ Stasiun } & \multirow{3}{*}{$\begin{array}{l}\text { Curah } \\
\text { Hujan } \\
(\mathrm{mm})\end{array}$} & \multirow{3}{*}{\multicolumn{2}{|c|}{$\begin{array}{c}\text { Hujan Kawasan } \\
(\mathrm{Rh})\end{array}$}} \\
\hline & \multirow{2}{*}{$\begin{array}{c}\text { Mapane } \\
0.257 \\
\end{array}$} & \multirow{2}{*}{$\begin{array}{l}\text { Saojo } \\
0.743 \\
\end{array}$} & & & \\
\hline & & & & & \\
\hline 2011 & \multirow{4}{*}{$\begin{array}{l}\text { Tidak ada } \\
\text { Data }\end{array}$} & 77.00 & \multirow{4}{*}{$\begin{array}{c}\text { - Tidak } \\
\text { ada } \\
\text { - Data }\end{array}$} & 77.00 & 77.00 \\
\hline 2012 & & 79.80 & & 79.80 & 79.80 \\
\hline 2013 & & 84.30 & & 84.30 & 84.30 \\
\hline 2014 & & 89.40 & & 89.40 & 89.40 \\
\hline 2015 & 65.50 & 96.50 & 16.84 & 71.68 & 88.53 \\
\hline 2016 & 50.90 & 114.60 & 13.09 & 85.13 & 98.22 \\
\hline 2017 & 69.40 & 101.20 & 17.85 & 75.18 & 93.02 \\
\hline 2018 & 66.10 & 109.20 & 17.00 & 81.12 & 98.12 \\
\hline 2019 & 59.30 & 110.00 & 15.25 & 82.45 & 89.61 \\
\hline 2020 & 72.00 & 98.50 & 18.55 & 73.17 & 91.69 \\
\hline
\end{tabular}
minimal 10 tahun data runtut waktu [13].

Tabel 2. Data curah hujan menggunakan Metode Polygon Thissen

\subsection{Curah Hujan Rancangan}

Curah hujan rancangan adalah curah hujan yang terjadi pada suatu daerah dengan periode ulang tertentu. Dalam perhitungan curah hujan rancangan digunakan analisis frekuensi, akan tetapi sebelum menggunakannya perlu dikaji parameter statistik yang berkaitan dengan analisis frekuensi (Tabel 3).

Tabel 3. Kesesuaian pemilihan agihan frequensi

\begin{tabular}{cccc}
\hline No & Jenis & Syarat & Hitungan \\
\hline \multirow{2}{*}{1} & Distribusi & $\mathrm{CS}=1.140$ & $\mathrm{CS}=0.049$ \\
\cline { 3 - 4 } & Gumbel & $\mathrm{CK}=5.4$ & $\mathrm{CK}=1.590$ \\
\hline \multirow{2}{*}{2} & Distribusi & $\begin{array}{c}\mathrm{CS}=\text { Selain } \\
\text { Lilai diatas }\end{array}$ & $\mathrm{CS}=-0.608$ \\
\cline { 3 - 4 } & Person III & $\begin{array}{c}\mathrm{CK}=\text { Selain } \\
\text { Nilai diatas }\end{array}$ & $\mathrm{CK}=1.663$ \\
\hline
\end{tabular}

Berdasarkan harga $\mathrm{Cs}$, $\mathrm{Ck}$, dan $\mathrm{Cv}$ maka analisis frekuensi yang paling sesuai dan memenuhi syarat adalah analisis frekuensi Log Pearson III. Untuk mendapatkan harga XT (Hujan Rancangan), maka harga KTr diberi nilai sesuai dengan harga Cs (koefisien Skewness) dan kala ulang, dari harga-harga tersebut dapat ditarik suatu garis

\begin{tabular}{|c|c|c|c|c|c|c|}
\hline Tahun & $\begin{array}{l}x \\
0 \\
0 \\
\Theta \\
\text { Un } \\
\end{array}$ & 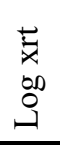 & CS & $\mathrm{KTr}$ & $\begin{array}{c}Y= \\
\log X\end{array}$ & $\begin{array}{c}\text { Hujan } \\
\text { Rancangan } \\
\text { (Xt) }\end{array}$ \\
\hline 2 & \multirow{6}{*}{$\begin{array}{l}\hat{n} \\
0\end{array}$} & \multirow{6}{*}{ ñ } & \multirow{6}{*}{$\begin{array}{l}\infty \\
0 \\
0 \\
0 \\
0\end{array}$} & 0.099 & 1.955 & 90,248 \\
\hline 5 & & & & 0.857 & 1.984 & 96.317 \\
\hline 10 & & & & 1.200 & 1.996 & 99.196 \\
\hline 25 & & & & 1.528 & 2.009 & 102.029 \\
\hline 50 & & & & 1.720 & 2.016 & 103.725 \\
\hline 100 & & & & 1.880 & 2.022 & 105.160 \\
\hline
\end{tabular}
lurus (Tabel 4).

Tabel 4. Perhitungan curah hujan rancangan Metode Log Person III 


\subsection{Perhitungan Intensitas Hujan}

Intensitas hujan adalah tinggi atau kedalaman air hujan per satuan waktu. Sifat umum hujan adalah makin singkat hujan berlangsung maka intensitasnya cenderung makin tinggi dan makin besar periode ulangnya. Dalam hal ini, hujan harian maksimum dipakai hujan rancangan berdasarkan kala ulang tertentu. Pada metode Mononobe, hujan harian dialihragamkan menjadi jam-jaman dengan mengetahui lama hujan, sedangkan lama hujan diketahui dengan menghitung waktu konsentrasi setiap DAS (Tabel 5).

Tabel 5. Perhitungan Intensitas Hujan

\begin{tabular}{ccccccc}
\hline Kala & \multirow{2}{*}{$\begin{array}{c}\text { R24 } \\
\text { Ulang }\end{array}$} & \multicolumn{6}{c}{ Intensitas Hujan } \\
\cline { 3 - 7 } & $(\mathrm{mm})$ & 1 & 2 & 3 & 4 & 5 \\
\hline 2 & 90.248 & 31.221 & 19.677 & 15.021 & 12.402 & 10.689 \\
\hline 5 & 96.317 & 33.321 & 21.000 & 16.031 & 13.236 & 11.408 \\
\hline 10 & 99.196 & 34.317 & 21.628 & 16.510 & 13.631 & 11.749 \\
\hline 25 & 102.029 & 35.297 & 22.246 & 16.981 & 14.020 & 12.084 \\
\hline 50 & 103.725 & 35.883 & 22.616 & 17.264 & 14.253 & 12.285 \\
\hline 100 & 105.160 & 36.380 & 22.928 & 17.502 & 14.451 & 12.455 \\
\hline
\end{tabular}

3.4. Perhitungan Hidrograf Satuan Sintetik Snyder Alexejev

Parameter yang digunakan dalam analisis Hidrograf Satuan Sintetik (HSS) Snyder sebagai berikut:

- Luas DAS (A)

$$
\begin{aligned}
& =1092.81 \mathrm{~km}^{2} \\
& =74.58 \mathrm{~km} \\
& =37.29 \mathrm{~km} \\
& =0.9 \\
& =1.20 \\
& =1 \text { Jam }
\end{aligned}
$$

- Titik Berat DAS (Lc)

- Koefisien Kelandaian (Ct)

- Waktu Hujan Efektif (tr)

Dari parameter diatas akan dilanjutkan dengan mencari Hidrograf Satuan Sintetik dengan beberapa faktor faktor, antara lain:

1) Menghitung waktu mulai hujan (tp).

$\mathrm{Tp}=12.955 \mathrm{jam}$

2) Menghitung waktu lama curah hujan (te)

te $=2.355 \mathrm{jam}$

3) Menghitung waktu dasar (Tb)

$\mathrm{Tb}=67.276$ jam

4) Menghitung waktu mencapai puncak banjir (Tp)

$\mathrm{Tp}=12.616 \mathrm{jam}$

5) Menghitung Debit Puncak (Qp)

$\mathrm{Qp}=21.672 \mathrm{~m}^{3} / \mathrm{det}$

\subsection{Perhitungan Hidrograf Satuan Sintetik Soil Conversation Service (SCS)}

Parameter yang digunakan dalam analisis Hidrograf Satuan Sintetik (HSS) Soil Conversation Service sebagai berikut:

- Luas DAS (A)

- Panjang Sungai (L)

- Waktu Hujan Efektif (tr)

$=1092.81 \mathrm{~km}^{2}$

$=74.580 \mathrm{~km}$

$=1 \mathrm{jam}$

- Kemiringan Sungai (S)

$=0.0859$

- Curva Number $(\mathrm{CN})$

- Kelompok Tanah
1) Curva Number $(\mathrm{CN})=78.85$

2) Time lag $(T l)=10.453 \mathrm{jam}$

3) Waktu lama curah hujan (te) $=1.900$ jam

4) Waktu dasar ( $\mathrm{Tb})=57.268$ jam

5) Waktu mencapai puncak banjir $(\mathrm{Tp})=10.954$ jam

6) Menghitung debit puncak (Qp) $=20.751 \mathrm{~m}^{3} / \mathrm{det}$

\subsection{Hujan Rancangan}

Pada kedua metode tersebut metode yang masuk kriteria ialah metode Log Person III. Dengan menggunakan parameter Statistik $\mathrm{Cs}, \mathrm{Ck}$, dan $\mathrm{Cv}$ dilanjutkan dengan menghitung besarnya Probabilitas Hujan Rancangan dengan menggunakan metode Uji Kecocokan, metode yang digunakan ialah Uji Chi Square dan Smirnov Kolmogorov.

a) Analisis berdasarkan nilai parameter Pada metode Snyder waktu yang dibutuhkan untuk sampai ke puncak banjir (Tp) sebesar 12,616 Jam sedangkan pada metode Soil Conversation Service (SCS) waktu yang dibutuhkan untuk sampai ke puncak banjir (Tp) sebesar 10.954 Jam perbedaan dari kedua metode tersebut sebesar 1.663 jam (Tabel 6).

b) Analisis berdasarkan nilai parameter

Pada metode Snyder waktu yang dibutuhkan dari awal sebelum mulai banjir hingga banjir surut $(\mathrm{Tb})$ sebesar 67.276 Jam, sedangkan pada metode Soil Conversation

\begin{tabular}{|c|c|c|c|}
\hline \multirow{2}{*}{ Parameter } & \multicolumn{2}{|c|}{ Metode HSS } & \multirow{2}{*}{ Satuan } \\
\hline & Snyder & $S C S$ & \\
\hline Waktu Puncak (Tp) & 12.616 & 10.954 & jam \\
\hline Waktu Dasar (Tb) & 67.276 & 57.268 & jam \\
\hline Debit Puncak (Qp) & 21.672 & 20.751 & $\mathrm{~m}^{3} / \mathrm{det}$ \\
\hline
\end{tabular}
Service (SCS) waktu yang dibutuhkan dari awal sebelum mulai banjir hingga banjir surut $(\mathrm{Tb})$ sebesar 57.268 Jam, perbedaan dari kedua metode tersebut sebesar 10.008 Jam.

Tabel 6. Nilai Parameter

c) Analisis Berdasarkan Debit Banjir Terbesar

Berdasarkan hasil perhitungan didapatkan debit banjir terbesar terjadi pada metode Hidrograf Satuan Sintetik Snyder (Gambar 3, Gambar 4 dan Gambar 5).

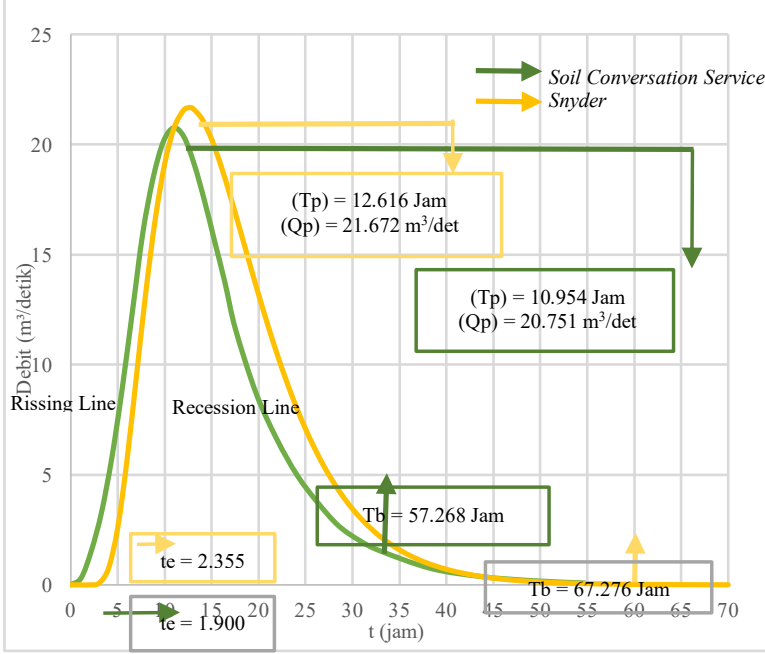

Gambar 3. Grafik hubungan antara debit dengan waktu 


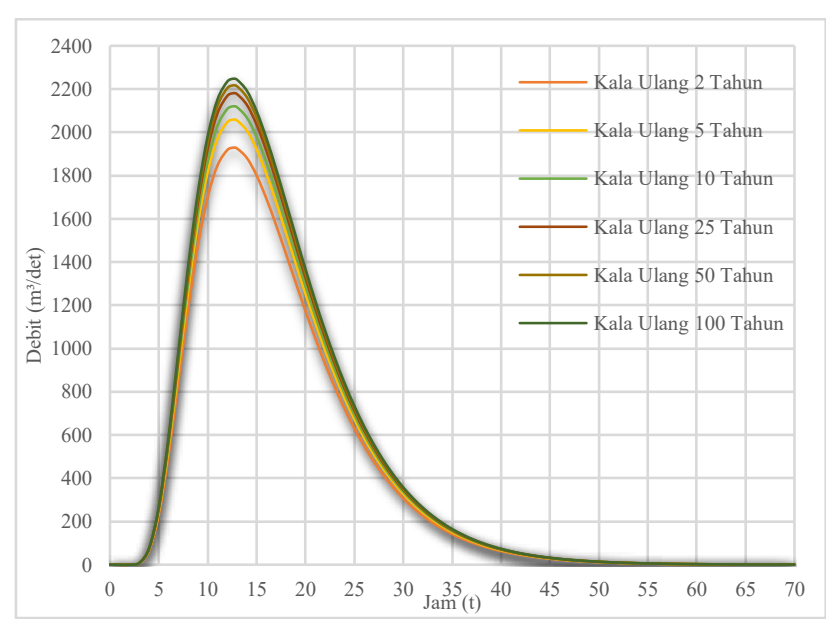

Gambar 4. Grafik kala ulang 2-100 tahun Metode Snyder.

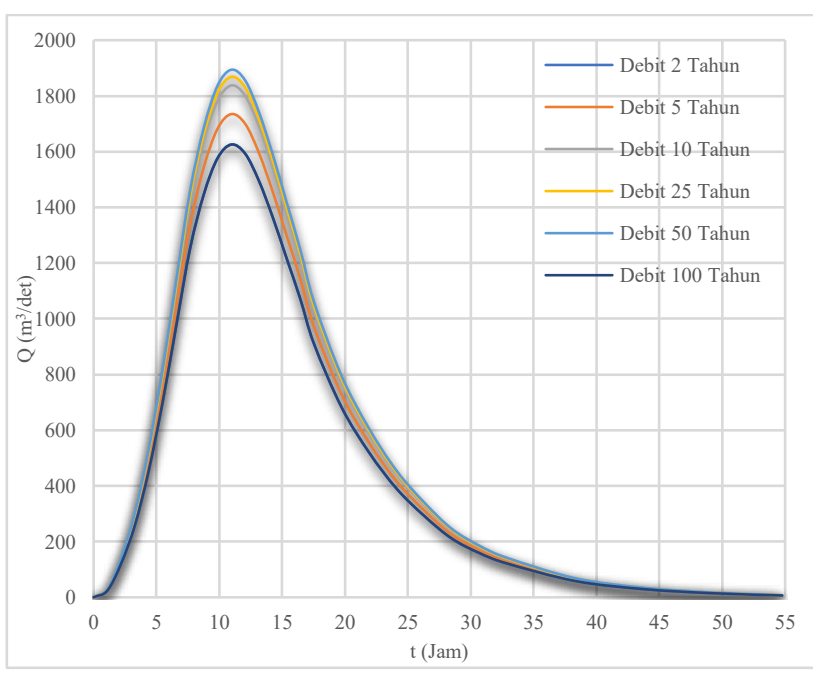

Gambar 5. Grafik kala ulang 2 - 100 tahun Metode Soil Conversation Service.

\section{Kesimpulan}

Berdasarkan hasil analisis Hidrograf Satuan Sintetik menggunakan metode HSS Snyder dan HSS Soil Conversation Service (SCS), maka dapat ditarik kesimpulan bahwa:

1) Debit Banjir Terbesar

Berdasarkan hasil analisis debit banjir dengan menggunakan metode HSS Snyder dan HSS Soil Conversation Service (SCS) debit banjir terbesar pada daerah aliran sungai Poso terjadi pada metode HSS Snyder dengan debit banjir yang dihasilkan sebesar $21.672 \mathrm{~m}^{3} /$ det, dengan kala ulang $2-100$ tahun didapatkan nilai debit banjir sebesar 1929.004 $2247.728 \mathrm{~m}^{3} /$ det sedangkan pada metode Soil Conversation Service nilai debit banjir yang didapatkan sebesar $1625.263-1893.801 \mathrm{~m}^{3} /$ det.

2) Bentuk Hidrograf

Berdasarkan grafik debit banjir pada daerah aliran sungai Poso dengan menggunakan metode HSS Snyder dan HSS Soil Conversation Service (SCS), didapatakan hasil sebagai berikut :
- Pada metode Snyder jam ke 2.355 debit air akan mengalami waktu naik (rissing line) hingga mencapai waktu puncak (Tp) di jam ke 12.616. Debit puncak yang di hasilkan di waktu puncak sebesar $21.672 \mathrm{~m}^{3} /$ det. Setelah mecapai debit puncak, debit air akan mengalami sisi resesi (recession line) atau biasa disebut waktu dasar ( $\mathrm{Tb}$ ), waktu yang diperlukan sebesar 67.276 Jam.

- Pada metode Soil Conversation Service (SCS) jam ke 2 debit air akan mengalami waktu naik (rissing line) hingga mencapai waktu puncak (Tp) di jam ke 10.453. Debit puncak yang di hasilkan di waktu puncak sebesar $20.751 \mathrm{~m}^{3} /$ det. Setelah mecapai debit puncak, debit air akan mengalami sisi resesi (recession line) atau biasa disebut waktu dasar ( $\mathrm{Tb}$ ), waktu yang diperlukan sebesar 57.268 Jam.

\section{Daftar Pustaka}

[1] G. If'ki, “Analisa Model Hidrograf Banjir Kali Ngotok dengan Metode Scs, Snyder dan Nakayasu", Jurnal Bangunan, vol. 2, no. 2, p. 1, 2020.

[2] Konsultan Perencana, Master Plan WS Parigi-Poso, Palu: Balai Wilayah Sungai Sulawesi III, 2008.

[3] Paimin, Teknik Mitigasi Banjir dan Tanah Longsor, Balikpapan: Tropenbos International Indonesia Programme, 2009.

[4] C. Asdak, Hidrologi Pengolahan Daerah Aliran Sungai. Yogyakarta: Gajah Mada University Prees, 1995.

[5] Kementerian Pekerjaan Umum, Peraturan Menteri PU No. 39/1989 Tentang Pembagian Wilayah Sungai, Jakarta: Sekretariat Kementerian PU, 1989.

[6] Sosrodarsono and K. Takeda, Hidrologi Untuk Pengairan. Jakarta: Pradnya Paramita, 1978.

[7] I.M. Kamiana, Teknik Perhitungan Debit Rencana Bangunan Air, Yogyakarta: Graha Ilmu, 2011.

[8] C.D. Soemarto, Hidrologi Teknik, Jakarta: Erlangga, 1995.

[9] B. Triatmodjo, Hidrologi Terapan, Yogyakarta: Beta Offset, 2008

[10] V.T. Chow, Applied Hydrology, New York: Mc Grow-Hill Science Engineering, 1998.

[11] I.G. Tunas, Pengembangan Model Hidrograf Satuan Sintetik Berdasarkan Karakteristik Fraktal Daerah Aliran Sungai-Disertasi S3 No. 217 - 225, Surabaya: Institut Teknologi Sepuluh Nopember: 2007.

[12] S. Harto, Analisis Hidrologi, Jakarta: PT. Gramedia Pustaka Utama, 1993.

[13] R. Viji, P.R. Prasanna, and R. Ilangovan, "Modified SCS-CN and Green- Ampt Methods in Surface Runoff Modelling for the Kundahpallam Watershed, Nilgiris, Western Ghats, India", Aquatic ProcediaInternational Conference on Water Resources, 
Coastal and Ocean Engineering, vol. 4, p. 677-684, 2015.

[14] S. Samatan, "Perbandingan Perkiraan Debit Banjir Rancangan Menggunakan Data Hujan dan Debit di DAS Kaliwadas Kab. Pekalongan, Jawa Tengah", Rekonstruksi Tadulako: Civil Engineering Journal on Research and Development, vol. 1, no. 2, p. 1, 2020.

[15] E.E. Alhakim, A. Bondan, and E.R. Iswanto, "Perbandingan Hidrograf Satuan Sub-DAS Cisadane untuk Analisis Banjir Tapak RDNK Serpong, Jurnal Pengembangan Energi Nuklir, vol. 21, no. 2, p. 97, 2019.
[16] A.N.S. Sari, R. Pranoto, and V. Suryan, "Perhitungan Hidrograf Banjir dengan Metode Hidrograf Satuan Sintetis SCS (Soil Conservation Service) di Kota Palembang", Journal of Airport Engineering Technology (JAET), vol. 1, no. 1, p. 1, 2020. 